\title{
Título da página electrónica: International Labor
} Rights Fund

Endereço: www.laborrights.org

Hermes Augusto Costa

\section{OpenEdition}

\section{Journals}

Edição electrónica

URL: http://journals.openedition.org/rccs/1321

DOI: $10.4000 /$ rccs. 1321

ISSN: 2182-7435

\section{Editora}

Centro de Estudos Sociais da Universidade de Coimbra

Edição impressa

Data de publição: 1 junho 2002

Paginação: 193

ISSN: 0254-1106

\section{Refêrencia eletrónica}

Hermes Augusto Costa, «Título da página electrónica: International Labor Rights Fund », Revista Crítica de Ciências Sociais [Online], 62 | 2002, posto online no dia 01 outubro 2012, consultado o 21 setembro 2020. URL : http://journals.openedition.org/rccs/1321 ; DOI : https://doi.org/10.4000/rccs 1321 


\section{Espaço Virtual}

\section{Título da página electrónica: International Labor Rights Fund Endereço: www.laborrights.org}

Criado na década de 80 e sediado em Washington D.C., o International Labor Rigths Fund (ILRF) é uma organização não governamental $(\mathrm{ONG})$ vocacionada para defesa dos direitos laborais básicos à escala mundial: a luta contra o trabalho infantil, o trabalho forçado e outras práticas abusivas dos direitos dos trabalhadores são as suas principais linhas de força. A página da instituição reflecte essa preocupação central, desde logo pelo vasto leque de projectos de investigação em que o ILRF está envolvido, nalguns casos conjuntamente com outras ONGs e universidades, sendo possível extrair artigos completos dos intervenientes nos projectos (o projecto "tra- balhadores na economia global" é, entre outros, um bom exemplo disso). A própria secção "artigos e discursos" encontra-se estruturada por temas, o que facilita a pesquisa de estudiosos e interessados nestes domínios, ainda que o leque de referências indicadas seja pouco vasto.

O site está estruturado de forma simples e é de fácil acesso. Para além da actualização constante relativa às violações laborais à escala mundial, rotuladas como "acções urgentes”, na página disponibilizam-se também outros endereços de outras organizações (sindicais, académicas, de direitos humanos, governamentais, etc.) de objectivos análogos aos do ILRF.

\section{Título da página electrónica: International Labour Organization Endereço: www.ilo.org}

A página da Organização Internacional do Trabalho (OIT) fornece-nos uma rápida, actualizada e diversificada informação sobre a situação do trabalho no mundo, com destaque para: os padrões, direitos e princípios fundamentais no trabalho; o emprego; a protecção social; e o diálogo social. O principal mérito da página - a diversidade de informações, dados, estudos e indicadores sobre o mercado de trabalho mundial - não esconde também a fraqueza resultante da sensação de dispersão gerada pelo excessivo número de itens que se deparam aos navegadores assim que abrem a página. Felizmente, porém, o sitemap da página contém praticamente toda a infor- mação ordenada sobre as actividades e serviços da OIT. O "motor de procura" que encabeça esse "mapa" é bastante eficaz, permitindo pormenorizar a informação pretendida por país e assunto.

Disponível em inglês, francês e espanhol, a página permite ainda acesso directo à versão electrónica da revista International Labour Review (trilingue), bem como à biblioteca central da OIT e a outras publicações, entre as quais se contam relatórios e bases de dados actualizados por assunto. Sem dúvida, uma página de grande utilidade tanto para especialistas das questões do trabalho como para o cidadão comum. 


\section{Título da página electrónica: International Confederation of Free Trade Unions \\ Endereço: www.icftu.org}

Embora se trate da maior organização sindical mundial e tenha completado já meio século de vida, só a partir de 1996 é que a Confederação Internacional dos Sindicatos Livres (CISL) despertou para o sindicalismo online. Tal como sucede com a página da OIT, parece excessivo o número de itens com que se deparam os cibernautas que entram na página. Em todo o caso, a igualdade no trabalho, os direitos sindicais, as empresas multinacionais, a globalização e seus impactos sobre o trabalho, o comércio e os padrões laborais são, entre outros, alguns dos temas recorrentes sobre os quais se podem encontrar quase sempre informações detalhadas e actualizadas nesta página.

Este site é ainda de grande utilidade enquanto instrumento de campanha e mobilização sindical, permitindo a ligação com outras organizações sindicais, a troca de informações e a partilha de experiências comuns, nomeadamente através do "global unions" (gerido por várias organizações sindicais internacionais) ou do "global compact” (das Nações Unidas). O serviço de obtenção de informações via email que a página disponibiliza é de resposta rápida e eficiente.

\section{Título da página electrónica: European Foundation for the Improvement of Living and Working Conditions Endereço: www.eurofound.eu.int}

Além de atractiva, a página da Fundação Europeia para a Melhoria das Condições de Vida e Trabalho (que realiza estudos de apoio à política social da UE) encontra-se extremamente bem ordenada. As três áreas-chave da Fundação são as condições de vida e de trabalho e as relações laborais. É, porém, nesta última área que melhor se atesta o trabalho da Fundação e se revelam as qualidades da página.

Os desenvolvimentos operados nas "relações laborais" europeias podem ser acompanhados através de três instrumentos: o Observatório Europeu de Relações Laborais (que fornece estudos comparados por tema, país e sector de actividade); o Glos- sário Europeu de Emprego e Relações Laborais (que permite um conhecimento da terminologia usada no domínio das relações laborais por país); e a base de dados sobre Conselhos de Empresa Europeus (instituições de informação e consulta dos trabalhadores nas empresas multinacionais). Para além de rica, toda a informação está bastante actualizada. Quase sempre é possível fazer download dos estudos, documentos e publicações disponíveis, o que confere ainda maior utilidade a esta página.

\section{Hermes Augusto Costa \\ hermes@sonata.fe.uc.pt}

